Article

\title{
The Impacts of Spatial Planning on Degrowth
}

\section{Petra Wächter}

Institute of Technology Assessment of the Austrian Academy of Sciences, Strohgasse 45/5, 1030 Vienna, Austria; E-Mail: petra.waechter@oeaw.ac.at;

Tel.: +43-1-51581-6592; Fax: +43-1-7109883

Received: 8 November 2012; in revised form: 31 January 2013 / Accepted: 4 February 2013 /

Published: 7 March 2013

\begin{abstract}
As the current growth economy has created severe environmental pollution and unbalanced distribution of prosperity, there is an increasing amount of critical voices calling for a change. The new concept of degrowth addresses a fundamental change in political, economic and institutional levels underpinning different norms and values towards sustainability. Spatial planning institutions have a decisive role in the transition process insofar as they take decisions regarding the use of land and its attributed space. Especially in three areas spatial planning has influential potentials to stimulate the transition process towards degrowth by enhancing: (i) a sustainable use of renewable energy sources; (ii) sustainable settlement structures; and (iii) the creation of social capital by more community based facilities. The paper explores these possibilities for intervention and shows how spatial planning can have positive impacts on degrowth.
\end{abstract}

Keywords: degrowth; spatial planning; settlement structures

\section{Introduction}

Economic growth and how it is measured has been in the center of criticism for decades. The basis of this criticism is that in a biophysical system with finite resources it is impossible for an economy based on these resources to grow infinitely. The new movement of degrowth, i.e., socially sustainable economic degrowth, gives insight into a more holistic approach towards less exploitation of natural resources, more worldwide equality and a better quality of life. Human progress does not rely on growth enhancing market relations but instead the focal point of interest should be placed upon the broadening of human relationships and the deepening of democracy [1]. Degrowth should not be seen 
as the counterpart of growth nor as a form of economic recession, but as a voluntary transition to a stadium of less production and less consumption.

In the discussion about degrowth and a sustainable use of resources land and how it is used, the basis of our daily lives and of all our activities, is sometimes forgotten about. In this context, spatial planning institutions have a decisive role to play in determining land use and are responsible for the planning, structure and design of landscapes. There are in particular three aspects in which spatial planning is a crucial factor for degrowth: Firstly, on the one hand, energy demand depends on how land is structured, and on the other, spatial planning can influence if and how renewable energy sources are used. Secondly, how settlements are structured and what this means for resource use also lies in the hands of spatial planning institutions. Thirdly, settlement structures have an impact on the social organization of their inhabitants and on the formation of social capital. This shows how spatial planning as a cross-sectional issue affects relevant topics for sustainable degrowth.

The aim of this paper is to focus on the role that spatial planning institutions can play as an example for institutional change towards sustainable degrowth. It wishes to show the institutions' importance in a transition process by portraying the role these institutions play in the production process of renewable energy and in deciding about settlement structures that in turn influence social capital. Further, it addresses the potential that spatial planning institutions already have which can serve as a point of conduct for a transition towards sustainable degrowth to avoid abrupt societal changes. Based on findings from studies of the area of spatial planning the paper provides theoretical considerations and concrete experiences how spatial planning can enrich the discourse about sustainable degrowth.

The paper is structured as follows: After the introduction in Section 1, Section 2 describes the origins and some of the claims of the currently emerging degrowth movement. Section 3 illustrates the importance of spatial planning and its institutions concerning renewable energy sources, explores the potential of settlement structures for sustainable degrowth and emphasizes the importance of multi-functional settlement structures for the building of social capital. The paper ends with the conclusions in Section 4.

\section{Sustainable Degrowth}

The term "degrowth" has its origins in the French word "décroissance" and tries to capture the manifold paths of a transition to sustainability on different levels of approaches. The catchword "degrowth" addresses a voluntary transition to lower levels of material throughput and less materialistic wealth. However, degrowth is much more than just that. The concept of degrowth in the scientific community attracts those scholars who deal with the limits of economic growth and search for alternative paths to prosperity [1-4]. As a political approach degrowth includes democracy, equality, justice, and self-determination aimed at a society with more direct democracy enhancing structures than we have at present $[5,6]$. Last but not least degrowth is a social movement including numerous groups, initiatives and associations around the globe [1,7], which advocate values and norms other than the growth paradigm in a large number of projects and initiatives. What defines degrowth is that it incorporates all three strands of approaches in a complementary manner, which can indeed be considered as a new attempt to a transition towards global sustainability. 
Less environmental pollution, less resource use and less energy use are not only claims of degrowth. Whereas other theories such as Green Growth see dematerialization and efficiency improvements as the key-solution to current environmental problems, degrowth emphasizes changing the underlying system that has caused this severe environmental depletion [8]. If current economic growth rates continue, the envisaged climate stabilization target of $450 \mathrm{ppm}$ in 2050 can only be reached, if efficiency improvements are ten times faster each year than it is currently the case [9], which is not feasible. Renewable energy sources provide a clean alternative to fossil energy sources in most cases, but also hold the danger of overusing ground, water, air and of needs which are in competition with each other, as the ongoing "food $v s$. fuel" debate shows. As no options exist that could bring energy and resource use to sustainable levels with the current technology, a call for less resource use is the only alternative left. This development has to go hand in hand with a change of institutions, culture and societal networks, which would not be successful in any other way.

Institutional change is needed where the capitalist rationality is subordinated towards an eco-social rationale in which economic activities are subordinated to social and ecological imperatives. The institutions are also criticized because they tend to create multiple impediments to people's autonomy [2]. Although there is no clear concept so far of which institutions should change in what way, there is a general agreement within the degrowth-community that the aim of a post-capitalist alternative requires institutional breaks. Examples of 'new degrowth institutions' include institutions that guarantee a minimum of health and economic security to all [4]. To incorporate the plurality needed in a degrowing society from the beginning, new institutional settings should emerge from bottom-up rather than be implemented from top-down.

Degrowth can also be seen through the concept of natural and social capital. In economic terms, natural capital refers to any stock of natural assets that brings a flow of monetarily valued goods and services. Social capital refers to features of social organisation such as networks, norms or trust which increase a society's productive potential. Social capital can also be seen as a public good since it is not private property of those who benefit from it. What is actually demanded by the degrowth movement is a substantial decrease of the use of natural capital towards sustainable levels without any depletion of natural resources [10]. Instead, social capital should be enhanced, meaning that all features of social capital should be in the focus such as knowledge, understandings or interpersonal interactions. These skills are used to build on bonds of information, trust and interpersonal solidarity. Social capital is not limited by material scarcity and is not driven by illogical thinking of unlimited growth within finite resources. On the contrary, social capital can be increased nearly infinitely and is only constrained by the capabilities of human nature. Therefore, the increase of social capital stands for a basic claim within the degrowth movement: orientation towards values other than unlimited growth.

Spatial planning institutions constitute one of the many institutions that have an impact on energy use, institutional framing and social capital. The crosscutting research field of spatial planning gives theoretical foundations on how the use of land is structured and where regions, cities, villages, and settlements are located and how they are organized. In practice, it is spatial planning institutions, which take decisions over land use mainly by enforcing the strong instrument of dedication of land. According to the powerful decisions of spatial planning institutions, how many resources are needed is determined and how the design of landscapes and cities is to be performed. As these structures also 
determine the organization of daily activities embedded in a social environment, they are decisive for social skills and relationships subsumed under the notion of social capital. Therefore, the intention of this paper is to further explore how spatial planning institutions could enable a structural framework which contributes to a transition towards degrowth.

\section{Sustainable Spatial Planning for Degrowth}

Economists quickly recognized that land has a special role in economic production as it is impossible to augment the amount of land which is, therefore, much less elastic than the supply of capital goods [11]. Late in the 20th century, land and environmental resources in general completely disappeared from the production function, leaving capital and labor as the only inputs [11]; later still capital is the only remaining input factor left. This trend even strengthens the view of endless substitution possibilities between input factors. However, this development leads to manifold criticism because certain aspects such as irreversibility, non-substitutability of production factors and the pervasiveness of external effects are not adequately reflected upon. Moreover, more recent approaches replace land (and also natural resources) with their assigned monetary values. As land and its use has a key function in living and production processes it can be regarded as its basis.

Spatial planning institutions have the power to decide over land and its use. Depending on national regulation, they differ widely in range and scope and in particular in competences on a local, regional and national level. The perspective taken here focuses mainly on the Austrian situation, but is applicable to all countries where spatial planning institutions have a similar structure and competencies. However, spatial planning institutions operate largely on a regional basis and can be regarded as one of the responsible institutions for local environmental development. Even more, spatial planning institutions are decisive in forming a region's infrastructure and its further development, as they are the determining authority that decides where and which infrastructure is built and maintained [12]. The possibilities of intervention can be found in the strong instrument of dedication of land, further the use for (renewable) energy purposes, for infrastructure of transport, for settlements, commerce and industry as well as in planning decisions in local and regional spatial development concepts and in local planning maps. Therefore, spatial planning authorities can be regarded as one of the influential institutions in the organization of basic needs such as food, housing or work and they can determine the conditions for daily life to a large extent.

\subsection{Renewable Energy Sources for Sustainable Settlements}

Energy and land use are mutually connected: on the one hand, the production and utilization of energy has impacts on land use and, on the other hand, the use of land determines energy consumption [13]. A sustainable energy system aiming at less GHG emissions has to rely on renewable energy sources, which need a greater amount of land per unit of produced energy than exhaustible energy sources, especially the use of biomass but also solar energy or wind on a large scale. This focuses increased attention on the intertwined relationship between energy and land use. Land use can be considered as "the most important environmental consideration in the development of these resources" [14], because land needs are a potential constraint to make use of renewable energy sources. How land use is planned and organized largely determines energy 
consumption. It is estimated that more than half of the energy demand in the developed world can be assigned to the arrangement of land uses [15].

Although the use of renewable energy sources is not free from controversies, they constitute the basis for each sustainable energy system. As the availability of renewables differs widely within time and the seasons as well as location, each region and even each municipality has its own possibilities to make use of the supply of renewables on site. A more regional based energy supply therefore requires more intensified regional spatial planning. Spatial planning institutions play an important role insofar as they can provide detailed resource plans for each region and municipality to demonstrate the expected potentials each renewable energy source offers (see, e.g., for Austria [16]). Further, the strong instrument of dedication of land makes it possible to use the envisaged potentials as they give the legitimacy to use land for the production of renewable energy. Nonetheless, the potential sustainable renewable energy sources provide is likely to be overestimated, if the energy needed to produce energy, i.e., their energy return on investment (EROI) is taken into account [17]. Therefore, it has to be doubted that the sustainable use of renewable energy sources can satisfy current energy demands, which means on the one hand a reduction in energy use and on the other a comprehensive re-organization of energy production and use.

Energy-conscious spatial planning also depends on settlement structures. Existing settlements can adapt according to their possibilities ranging from building new power plants using renewables to installing solar panels on roofs and façades of houses. Newly built settlements should be placed where the supply of renewables is on site or nearby. The use of certain energy sources also depends on the settlements' densities: in settlements with higher density, local heating systems are recommended whereas in lower density settlements solar energy may be the more useful alternative. If the potential supply of renewables is limited, municipalities and regions can seek out co-operations in their adjacent surroundings for regional energy networks. It is especially this aspect which is essential for spatial planning institutions, as they can make a contribution for such co-operations in providing spatial information on energy resources, on potential sites for power plants and on energy concepts and models.

One important differentiation has to be made between renewables for heat production and renewables for electricity production. While the distance between heat production and its use should be as short as possible to avoid thermal losses, the distance from electricity production to its use can be much larger because even in far distances losses through transport are smaller. Nevertheless, most favorable electricity production remains on site which means placing the production sites on the most suitable places. As some forms of electricity production such as using wind power can provoke local resistance it is unavoidable to incorporate local population in decisions about power plants. In support of a sustainable use of renewable energy sources, spatial planning institutions should make use of their planning competencies in regard of a sustainable management of land use for renewables.

The special role spatial planning institutions can play is to ensure a sustainable use of renewables, i.e., to avoid any overuse of land, water and air. Spatial planning has to respect the limits of sustainable resource use and to secure that no irreversible damage is done by the use of renewables. While sustainability goals are established in most guidelines of spatial planning institutions, their concrete formulation remains vague and full implementation is rare. The call for more energy-conscious spatial planning $[18,19]$ is not new to the planning community and within the 
degrowth community the potential of spatial planning institutions to contribute to a more sustainable use of energy sources has not been sufficiently addressed so far. Although the connection of energetic metabolism and space has already gained attention [20], spatial organization and its impacts on energy demand are hardly discussed. In the organization of a sustainable energy system, it is essential to incorporate spatial planning institutions.

\subsection{Sustainable Settlements for Sustainable Degrowth}

Over the past few decades many industrialized countries have been confronted with an unsustainable development of land use and settlement structures. Ongoing tendencies show an increased per capita land use in developed countries, for example in Austria sealed area per capita nearly tripled in fifty years from $200 \mathrm{~m}^{2}$ in 1955 to $560 \mathrm{~m}^{2}$ in 2005 . The main reasons for this development can be found in the increased demand for single and two family houses, for industrialized and commercial sites and their related infrastructure, and in the increasing infrastructure for mobility. Together with an intensified use of agricultural areas the process of an increase of sealed area above sustainable limits continues. In Austria, the sustainable limit of an increase of sealed area is set by $1 \mathrm{ha}$ /day but current development shows an increase of $7.5 \mathrm{ha} /$ day which is far above the envisaged goal. Although this indicator neglects the intensity of use, it clearly shows how much area is in human use and not available for ecological functions [21].

In the field of spatial planning, two phenomena related to increased land use are to be dealt with: urban sprawl and mono-functional settlement structures [22]. Urban sprawl is the term for unregulated development of settlements often leading to dispersed settlements and is regarded as a result of societal organization in space and time [22]. This development of urban sprawl was possible because land in the open country was more affordable than the one near the big cities and energy prices were cheap enough to upkeep the houses $[23,24]$ and to use motorized individualized transport, e.g., own cars [25]. Therefore, there has been a steady rise in mono-functional settlements with living purposes only, which in turn has led to a huge increase in commuter traffic. Apart from the traffic causing GHG emissions and noise, the required network of streets cuts through ecologically important connections within areas, and the habitat of fauna and flora. Besides, mono-functional settlements lack a mix of daily needed amenities such as working places, shops, recreational facilities, schools, kindergartens, health services and so forth [26]. The missing infrastructure enhances the overuse of resources even more, as well as making journeys more time consuming than necessary compared to where used infrastructure is in place. Moreover, spreading settlement structures increase the costs of construction and maintenance of infrastructure systems, especially the costs of systems depending on networks and grids increase substantially. At the same time, infrastructure facilities in cities have to be closed while being newly opened in the suburban areas, the costs of which have to be taken over through public expenses. Therefore, it is urban sprawl as well as mono-functional settlement structures that enhance immense resource use and high societal costs.

For decades, a number of driving forces has caused unfavourable developments of urban sprawl [22]. First, settlement structures themselves produce certain patterns of location and mobility, such as functional specification or social segregation. Political regulation enforces urban sprawl by instruments such as subsidies for single dwellings, tax incentives e.g., commuter tax allowances, land 
use planning or settlements of companies. Economical structural changes can lead to urban sprawl together with logistical concepts such as just-in-time-production or distribution of goods on the roads instead of on the rails. Additionally, behavioral and ideological changes lead to an idealized picture of "a happy family in their own single family house with a garden and a car in the driveway" which shows the societal requirement for success and status at the expense of increased land use. These drivers show explicitly how a society has developed and is organized in its attributed space.

As it is more difficult to push unsustainable settlements on a path towards sustainability than building new sustainable ones, the opinions on how to make the necessary transition differ widely. The most radical measure would be an expropriation of owners of dispersed settlements similarly to the expropriation for the building of new streets where the reasoning is based on overriding societal importance. A less forceful measurement consists of a process of redensification with the intention to make use of unused space within existing settlements. This provides the chance for spatial planning institutions to initiate multi-functional structures with a mix of daily needed infrastructure. If these facilities were within walking distance, in many cases less cars would be used [27,28]. In urban regions, revitalization and the (temporary) utilization of vacant buildings provides a possibility of structural change of unused dwellings. A different view expects this change to happen anyway when energy prices rise and this life-style becomes less affordable for less people, as high energy prices probably entail that present resources are more likely to be used on a communal basis.

Regarding options for further development of new settlements, spatial planning institutions are well advised to make use of the strong instrument of dedication of land. As dedication of land is the legal basis for the location of new dwellings, it lies in the hands of spatial planning institutions to foster or prohibit urban sprawl and other forms of unsustainable development of settlements. A further option consists of governing and curtailing the unregulated development of settlements by binding concepts and regulations in spatial development plans. One measure to restrict the consumption of resources consists of a quantitative limitation of daily greenfield consumption [29] which would be, at least in the case of Austria, an enforcement to respect sustainable limits.

As most settlements show uniqueness in some attributes, the identification of limiting factors for sustainable development has to be tackled by planning institutions [30]. The call for more sustainable infrastructure for settlements has existed for decades. As spatial planning institutions so far have not succeeded in implementing even minimum sustainability standards in planning issues in the present system in most Western countries, it is system-immanent structures that make the impact of spatial planning much weaker than it should be. Spatial planning forms the basis for the very important decision on where and how to live and is therefore indispensable for a transition towards degrowth. A concrete step towards sustainable degrowth lies in the claim for multifunctional and redensified settlement structures and neighborhoods [30] to secure less resource intensive living conditions and a minimum of daily needed infrastructure. The revitalization of unused buildings can serve as an example par excellence for degrowth, as it fulfills the need to re-use instead of produce something new and as mainly bottom-up initiatives try to make use of urban vacancies. There is also potential for spatial planning institutions to manage its utilization and further development towards sustainable degrowth. 


\subsection{Enhancement of Social Capital by Community Based Facilities}

Multifunctional settlement structures are a valuable contribution to facilitate more community-based activities, which make use of the synergy effects that these structures offer. As theories on spatial organization suggest, it is not so much socio-economic indicators such as income, household size or age but rather the influence of social background and life-styles that influence urban sprawl [31]. The impact population density has depends mainly upon the organization of society in space which is regarded rather as a qualitative indicator than just the quantity and intensity of land use [22]. Therefore, it is all the more important to consider the structural impact of spatial organization on social actors who produce the sprawl.

Setting up more potential meeting places for citizens than in mono-structured settlements makes them a starting point for interaction on the one hand. On the other hand, contact nodes are a valuable basis for the creation of a sense of community where personal contacts can be made and established. These interpersonal relationships are the basis for finding common interests and common needs that could be fulfilled on a mutual basis. These community based services can include child care and care of the elderly, dog-walking, car pools, bike repair shops, food cooperatives or community gardening. Community based services and activities apply at least to one of the pillars of sustainable degrowth: the need for income from wage work could be reduced substantially if available infrastructure of services was provided on a non-monetary basis, which complies fully with the claim to less wage-paid working hours [3]. Moreover, these activities can be organized in a self-esteemed and democratic way, so the citizens themselves can make decisions over resources and services. The objectives are to take some of the power from the markets and the state into the hands of people from the community and to increase the community's self-reliance. This practice also provides a step towards more societal cooperation instead of ongoing individualization [32] and contributes to a rise of social capital.

Another effect is the positive impact and stimulant to regional economic circles. The creation of local employment opportunities in the form of worker co-operatives, community development corporations or even community land trusts could be supported and strengthened by spatial planning institutions in the form of multifunctional settlements. This provides a chance to strengthen the regional economy which does not necessarily mean a rise in regional GDP but gives room to new concepts of employment frames and conditions that contribute to a degrowing community. That includes reduced working hours or the legal and societal recognition of unpaid work. Multifunctional settlements provide a chance to increased self-sustaining economic networks reducing the social dependence on economic growth. The challenge for spatial planning institutions is to enable structures so that community based activities can be established and maintained.

It is not only multi-functional settlement structures that offer the potential to increase social capital but also citizens who demand multi-functional settlements. The possibility that spatial planning institutions could promote consists of enhancing a more democratic access in the planning processes [33]. In planning theory, the tradition of social mobilization states that the planer's role is one of community organization [34]. The involvement of local citizens, politicians or energy planners strengthens direct democracy and implies an institutional change in spatial planning. As the residents of a certain region are the ones that mainly use their land and buildings, they should also be the ones who take part in the decision process concerning their use. Besides, personal engagement is a form of 
taking over responsibility for the environment and the community and a form of identification with the living space. Therefore, such bottom-up processes support the increase of social capital in planning practices.

Positive examples describe the potential of self-organized cooperative help in construction issues, which is also oriented on ecological criteria [35]. Self-organized cooperatives as well as squatting projects in Germany were able to convince their opponents of the importance of ecological criteria and social improvement, e.g., by denying all attributes of luxurious settlements. With the support of spatial planning institutions as intermediates, it was possible to successfully initiate a process between the self-organized projects and governmental institutions. The projects were legalized and therefore had access to public subsidies to implement their plans. Years later, the results show that the living environment of these projects has a positive impact on employment, education and new self-organized socio-cultural infrastructure [35]. Spatial planning institutions, therefore, have shown to be a valuable factor for the enhancement of more sustainable living structures.

The potential for degrowth that spatial planning institutions can enforce is the increase of social capital by supporting the communal use of living infrastructure. Besides, the utilization of these services is not necessarily bound by any financial conditions of the citizens, if these services are based on mutual exchange and other helping activities. The involvement of all stakeholders in planning processes is a step towards democracy if those who are mainly directly concerned are involved in the decision-making. Spatial planning institutions have the possibility to take the role of communicator and mediator between all stakeholders involved.

\section{Conclusions}

In a society which is characterized by a growth discourse, institutions and their related infrastructure are organized and determined by the need to grow in all their varieties. Degrowth as a political concept clearly questions basic institutions concerning property or work which enable the framework conditions for growth to take place. Spatial planning institutions as part of a political system are one of the institutions facilitating growth by, e.g., unsustainable structures of land use. Their crucial role consists of having the authority decide by whom and for what purposes land-i.e., the basis for all resources - is allowed to be used. Spatial planning institutions have the power to design landscapes and their infrastructure and they have an essential influence on whether these structures enable growth or are oriented towards the needs of the population in a sustainable way. Spatial planning has powerful instruments to guide developments in certain directions, as it is obvious in the case of land dedication. Although the current practices of spatial planning institutions are not degrowth oriented, some of them constitute a valuable support towards degrowth. These practices should be regarded as points of conduct to enhance further change towards degrowth, as a smooth transition is made easier if some links to the current situation exist. Spatial planning institutions that orientate themselves on degrowth-aims, such as sustainable resource use, democracy or self-autonomy would be a decisive next step towards the progress of a degrowing society.

Spatial planning determines largely which and how many resources are needed and used. On the one hand, as the use of renewable energy sources largely depends on the availability of land, it lies in the hands of spatial planning institutions where and to what extent renewables are deployed. On the 
other hand, it is also spatial planning institutions that decide on the placement of settlements and how they are structured which in turn determines the consumption of resources. As a result, the ecological impact caused by decisions of spatial planning regards the amount of sealed area, energy demand or amount of traffic. Such a key role requires special attention in the degrowth discourse since spatial planning has powerful institutions deciding over basic living conditions. Although it is unrealistic to expect a settlement to fully sustain itself [36] if all needed flows of materials, money and people are considered, spatial planning institutions are valuable in enhancing structures that facilitate a less resource-intensive life style.

The formation and increase of social capital is one of the consequences of how settlements are organized. As spatial planning institutions are responsible for settlement structures, the conclusion can be drawn that spatial planning indeed is responsible for spatial socialization, which in turn influences the formation of social capital. How inhabitants perceive space also influences daily routines and activities. Space produces societal dispositions similar to money or status and is therefore essential when discussing societal transitions such as degrowth. Settlement structures are one example how the organization of space has impacts on social capital.

The democratic aspects of spatial planning are marked by land and who is allowed to dictate decisions on it. As equal access to natural resources is one of the main demands of the degrowth movement [37], this equal access has to start at the level where decisions on land use are taken. Since spatial planning presently does not allow local citizens to participate in the decision making process, the resulting top-down driven structures are not a reflection of the citizens' needs. A democratic access to decisions over land use would imply a right to decisions by the citizens who are the main users of the land in question. As long as land dedications are driven by economic interests - as in the case of land needs for biofuel production, or land needs for big shopping centers with no actual inhabitants, encouraging increased traffic - they do not approach democracy. In a Degrowth Research Proposal of the Second Degrowth Conference why there is no planning by people but only for people was questioned [38], which addresses exactly the missing self-autonomy by the users of land. A change in the institutions of property could convert land into a common good providing the chance of self-determination of its use.

This paper aims to contribute to the demand of the degrowth movement to change institutions which facilitate endless growth. It further wants to add to the discussion about institutions for degrowth by explicitly addressing spatial planning institutions. The paper discusses how spatial planning can influence settlement structures to enhance a life-style that accomplishes the aims of degrowth, emphasizing less resource use and more democratic structures. The future will show if the envisaged change will ever become a reality.

\section{Acknowledgments}

The author wishes to thank all participants of the second and third Degrowth-Conference for their valuable comments and discussions. Special thanks go to Michael Ornetzeder for commenting a prior version of this paper. The author is grateful to three anonymous reviewers whose valuable comments helped to improve the quality of the paper. 


\section{Conflict of Interest}

The author declares no conflict of interest.

\section{References}

1. Schneider, F.; Kallis, G.; Martinez-Alier, J. Crisis or opportunity? Economic degrowth for social equity and ecological sustainability. Introduction to this special issue. J. Cleaner Prod. 2010, $18,511-518$.

2. Martínez-Alier, J.; Pascual, U.; Vivien, F.-D.; Zaccai, E. Sustainable de-growth: Mapping the context, criticisms and future prospects of an emergent paradigm. Ecol. Econ. 2010, 69, 1741-1747.

3. Spangenberg, J.H. The growth discourse, growth policy and sustainable development: Two thought experiments. J. Cleaner Prod. 2010, 18, 561-566.

4. Kallis, G. In defence of degrowth. Ecol. Econ. 2011, 70, 873-880.

5. Latouche, S. Degrowth. J. Cleaner Prod. 2010, 18, 519-522.

6. Fournier, V. Escaping from the economy: The politics of degrowth. Int. J. Sociol. Social Policy 2008, 28, 528-545.

7. Cattaneo, C.; Gavaldà, M. The experience of rurban squats in Collserola, Barcelona: What kind of degrowth? J. Cleaner Prod. 2010, 18, 581-589.

8. Martínez-Alier, J. Socially sustainable economic de-growth. Dev. Change 2009, 40, 1099-1119.

9. Jackson, T. Prosperity without Growth-Economics for a Finite Planet, 1st ed.; Earthscan: Washington, DC, USA, 2009.

10. Ehrlich, P.R.; Kareiva, P.M.; Daily, G.C. Securing natural capital and expanding equity to rescale civilization. Nature 2012, 486, 68-73.

11. Hubacek, K.; van den Bergh, J.C.J.M. Changing concepts of "land" in economic theory: From single to multi-disciplinary approaches. Ecol. Econ. 2006, 56, 5-27.

12. Stremke, S.; Koh, J. Ecological concepts and strategies with relevance to energy-conscious spatial planning and design. Environ. Plann. B 2010, 37, 518-532.

13. Walker, G. Energy, land use and renewables. A changing agenda. Land Use Policy 1995, 12, 3-6.

14. Pasqualetti, M.J. The Land Use Focus of Energy Impacts. In Energy, Land and Public Policy; Cullingworth, J.B., Ed.; Transaction Publishers: New Brunswick, NJ, USA, 1990; pp. 99-136.

15. Owens, S.E. Land Use Planning for Energy Efficiency. In Energy, Land and Public Policy; Cullingworth, J.B., Ed.; Transaction Publishers: New Brunswick, NJ, USA, 1990; pp. 53-98.

16. ÖROK Austrian Conference for Spatial Development. Energie und RaumentwicklungRäumliche Potenziale Erneuerbarer Energieträger; ÖROK: Vienna, Austria, 2009.

17. Murphy, D.J.; Hall, C.A.S. Year in review-EROI or energy return on (energy) invested. Ann. NY Acad. Sci. 2010, 1185, 102-118.

18. Steiner, F. Human Eecology-following Nature's Lead; Island Press: Washington, DC, USA, 2002.

19. Ehrenfeld, J.; Gertler, N. Industrial ecology in practice: The evolution of interdependence at Kalundberg. J. Ind. Ecol. 1997, 1, 67-79. 
20. Sorman, A.H.; Giampietro, M. The energetic metabolism of societies and the degrowth paradigm: Analyzing biophysical constraints and realities. J. Cleaner Prod. 2013, 38, 80-93.

21. Siedentop, S. Urban sprawl—verstehen, messen, steuern. Ansatzpunkte für ein empirisches Messund Evaluationskonzept der urbanen Siedlungsentwicklung. DISP 2005, 160, 23-35.

22. Dangschat, J.S.; Kratochwil, S. Nicht-nachhaltige Trends in Österreich: Verkehr und Siedlungsentwicklung. In Forum Nachhaltiges Österreich; Forum Nachhaltiges Österreich: Vienna, Austria, 2005.

23. Rong, F. Residential energy use. Ph.D. Thesis, University of Maryland, Maryland, MD, USA, 2006.

24. Poumanyvong, P.; Kaneko, S. Does urbanization lead to less energy use and lower $\mathrm{CO}_{2}$ emissions? A cross-country analysis. Ecol. Econ. 2010, 70, 434-444.

25. VCÖ. Einfluss der Raumordnung auf die Verkehrsentwicklung; VCÖ Schriftenreihe Mobilität mit Zukunft 3/2007; VCÖ: Vienna, Austria, 2007.

26. Filion, P. Suburban mixed-use centres and urban dispersion: What difference do they make? Environ. Plann. A 2001, 33, 141-160.

27. Camagni, R.; Gibelli, M.C.; Rigamonti, P. Urban mobility and urban form: The social and environmental costs of different patterns of urban expansion. Ecol. Econ. 2002, 40, 199-216.

28. Gaffron, P.; Huismans, G.; Skala, F. Ecocity-A Better Place to Live; Facultas Verlags-und Buchhandels AG: Vienna, Austria, 2005.

29. Schetke, S.; Haase, D.; Kötter, T. Towards sustainable settlement growth: A new multi-criteria assessment for implementing environmental targets into strategic urban planning. Environ. Impact Asses. 2012, 32, 195-210.

30. Moles, R.; Foley, W.; Morrissey, J.; O’Regan, B. Practical appraisal of sustainable development-Methodologies for sustainability measurement at settlement level. Environ. Impact Asses. 2008, 28, 144-165.

31. Löw, M. Raumsoziologie, 1st ed; Suhrkamp Taschenbuch Wissenschaft: Frankfurt am Main, Germany, 2001.

32. Wächter, P.; Ornetzeder, M.; Rohracher, H.; Schreuer, A.; Knoflacher, M. Towards a sustainable spatial organization of the energy system: Backcasting experiences from austria. Sustainability 2012, 4, 193-209.

33. Hamedinger, A.; Bröthaler, J.; Dangschat, J.; Giffinger, R.; Gutheil-Knopp-Kirchwald, G.; Hauger, G.; Hirschler, P.; Kanonier, A.; Klamer, M.; Kramar, H.; et al. Räumliche Entwicklungen in österreichischen Stadtregionen-Handlungsbedarf und Steuerungsmöglichkeiten; ÖROK: Vienna, Austria, 2009.

34. Roseland, M. Sustainable community development: Integrating environmental, economic, and social objectives. Prog. Plann. 2000, 54, 73-132.

35. Knorr-Siedow, T. Handlungsfähigkeit durch Selbstorganisation und Selbsthilfe. In Planungskultur und Nachhaltigkeit-neue Steuerungs- und Planungsmodelle für eine nachhaltige Stadt- und Regionalentwicklung; Kühn, M., Moss, T., Eds.; VWF Verlag für Wissenschaft und Forschung: Berlin, Germany, 1998; pp. 213-229.

36. O'Regan, B.; Morrissey, J.; Foley, W.; Moles, R. The relationship between settlement population size and sustainable development measured by two sustainability metrics. Environ. Impact Asses. 2009, 29, 169-178. 
37. Degrowth Declaration of the Paris 2008 conference. J. Cleaner Prod. 2010, 18, 523-524.

38. Research Proposal on Cities and Degrowth of the 2nd Degrowth Conference Barcelona 2010. Available online: http://degrowthpedia.org/index.php?title=Working_groups_Barcelona_2010\# Cities_and_degrowth/ (accessed on 14 August 2012).

(C) 2013 by the authors; licensee MDPI, Basel, Switzerland. This article is an open access article distributed under the terms and conditions of the Creative Commons Attribution license (http://creativecommons.org/licenses/by/3.0/). 